\title{
Optimization and Performance Test of Oil Spill Dispersant at Bioremediation of Contaminated Soil with Heavy Oil by Bioslurry Technique
}

\author{
Muhammad Abdul Aziz ${ }^{*}$, Mohamad Yani and Agung Dhamar Syakti ${ }^{3}$ \\ ${ }^{1}$ Graduate School of Soil Biotechnology and Environment, Faculty of Agriculture, IPB University, Indonesia, \\ ${ }^{2}$ Department of Agroindustrial Technology, Faculty of Agricultural Technology, IPB University, Indonesia, \\ ${ }^{3}$ Marine science and Fisheries Faculty-Raja Ali Haji Maritime University, Tanjungpinang, Riau Island Province, \\ Indonesia.*e-mail: aziz.muh1992@gmail.com
}

Received October 14, 2019; Revised January 11, 2020; Accepted 16 January 2020

\begin{abstract}
Petroleum industry activities produce waste such as petroleum hydrocarbons which damage to the soil environment due to changes in soil physical, chemical and biological properties. Oil Spill Dispersant (OSD) is a product that can break down waste of oil into small parts so that it can be dispersed naturally. Laboratory experiments aimed to find out optimize and performance test of OSD in the process of bioremediation with using bio-slurry technique on contaminated soil with heavy oil was carried out at Laboratory of Surfactant and Bio-energy Research Center (SBRC), Research and Community Service Institute of Bogor Agricultural University on January - August 2018 using contaminated soil with heavy oil. The experiment used Response Surface Method (RSM) with two factors, namely the incubation time factor $\left(\mathrm{X}_{1}\right)$ and the Dispersant to oil ratio (DOR) $\left(\mathrm{X}_{2}\right)$. The observed variables were soil Total Petroleum Hydrocarbons (TPH), pH, total microbes, and Chemical Oxygen Demand (COD) at soil solution. The results showed that the treatment of incubation time and its combination with DOR significantly reduced soil TPH, increased soil acidity, and increased soil total B. megaterium, but did not significantly affect on COD in soil solutions. Optimization of OSD with RSM showed that the higher DOR of OSD and the longer the incubation time, the higher also the rate of biodegradation of TPH. The optimum conditions were reached at DOR of 1.16:1 and incubation time of 7 days which were able to degrade soil TPH of $54.30 \%$. The optimum conditions of soil $\mathrm{pH}(8.825)$ was reached at DOR of 1:1 and incubation time of 5 days, as well as the optimum conditions of B. megaterium (8.35 $\log \mathrm{CFU} \mathrm{g}^{-1}$ ) was reached at DOR of 0.86:1 and incubation time of 7 days. Oil spill dispersant (OSD) increased COD in soil solution in both uncontaminated and contaminated soils with heavy oil.
\end{abstract}

Keywords: Bioremediation, bioslurry, contaminated soil, heavy oil, oil spill dispersant

\begin{abstract}
ABSTRAK
Kegiatan industri perminyakan menghasilkan limbah seperti petroleum hydrocarbon yang merusak lingkungan tanah karena terjadi perubahan sifat fisik, kimia, dan biologi tanah. Oil Spill Dispersant (OSD) merupakan produk yang dapat menguraikan limbah minyak menjadi butiran-butiran kecil sehingga dapat terdispersi secara alami. Percobaan laboratorium yang bertujuan untuk mengetahui kondisi optimum proses bioremediasi dengan teknik bioslurry telah dilaksanakan di Laboratorium Surfaktan dan Bio-energy Research Center (SBRC), Lembaga Penelitian dan Pengabdian Masyarakat, Institut Pertanian Bogor (LPPM IPB) pada bulan Januari - Agustus 2018 dengan menggunakan contoh tanah yang tercemar minyak berat. Percobaan ini menggunakan Response Surface Method (RSM) dengan dua faktor, yaitu faktor waktu inkubasi $\left(\mathrm{X}_{1}\right)$ dan Dispersant to oil ratio (DOR) $\left(\mathrm{X}_{2}\right)$. Variabel yang diamati adalah Total Petroleum Hydrocarbons (TPH), $\mathrm{pH}$, total mikrob tanah, dan Chemical Oxygen Demand (COD) dalam larutan tanah. Hasil penelitian menunjukkan bahwa perlakuan waktu inkubasi dan kombinasinya dengan DOR nyata menurunkan TPH tanah, meningkatkan tingkat kemasaman tanah, dan meningkatkan total $B$. megaterium dalam tanah, tetapi tidak berpengaruh nyata terhadap COD larutan tanah. Hasil optimasi OSD dengan RSM menunjukkan bahwa semakin tinggi DOR OSD dan semakin lama waktu inkubasi, maka semakin tinggi pula tingkat biodegradasi TPH. Kondisi optimum tercapai pada DOR 1.16:1 dan waktu inkubasi 7 hari yang mampu mendegradasi TPH sebesar 54.30\%. Kondisi optimum pH (8.825) tercapai pada DOR 1:1 dan waktu inkubasi 5 hari,
\end{abstract}


serta kondisi optimum jumlah bakteri B. megaterium (8.35 $\log$ CFU $\mathrm{g}^{-1}$ ) tercapai pada DOR 0.86:1 dan waktu inkubasi 7 hari. Oil spill dispersant (OSD) meningkatkan COD larutan tanah baik pada tanah tidak tercemar maupun tanah tercemar minyak berat.

Kata Kunci: Bioremediasi, bioslurry, minyak berat, oil spill dispersant, tanah tercemar

\section{INTRODUCTION}

Oil industry activities such as exploration, exploitation, processing, and transportation have been increasing since the last decade. This is in line with the increase of human need on petroleum as the main energy source in developing industry, transportation, and households. Data from Central Bureau of Statistics Indonesia (2016) showed that oil consumption in Indonesia in 2015 reached 1.63 million barrels per day (bpd), which increased $15.9 \%$ in comparison to that in 2010. The greater the oil production, the greater the potential for environmental contaminations if the oil is spilled or discharged into the environment (soil and water). Oil contamination decreases the quality of soil, such as soil fertility, water holding capacity (WHC), permeability, as well as soil aggregate. This petroleum contamination also causes contamination of ground and surface water (Chithra et al. 2014).

Naturally, the environment is able to degrade the contaminants through physical, biological, and chemical processes. However, sometimes the level of contamination in the environment exceeds the ability of soil to naturally degrade these contaminants. As a result, contaminants will accumulate so that human intervention is needed to overcome the problem by using technology (Nugroho 2007). In order to avoid environmental contamination, petroleum waste management can be done with three approaches, namely physical, chemical, and biological approaches. Physical management is a direct waste management, such as filtering and absorption of the contaminants at locations of petroleum contaminated soil. However, this method looks like unable to overcome the petroleum contamination that enter into the soil. Chemical waste management is done by using chemical materials, so that in it will lead to contamination of others, due to the chemicals use. One alternative to overcome the contaminated environment is use of bioremediation techniques. The techniques are environmentally friendly, effective, and economical (Margesin et al. 2001; Liu et al. 2011; Dindar et al. 2013) by application of microbes. This techniques can also reduce the waste petroleum and produces by product of microbes (Jun et al. 2015 ).
Bioremediation techniques can be implemented at both in-situ and ex-situ ways. In-situ bioremediation techniques are generally use to on low contaminated environment, locations that cannot be moved, or on the environment which have characteristics of volatile contaminants. Ex-situ bioremediation is a technique of contaminated soil and water are removed, then treated and processed at special location. This management is save for the environment because of use of microbes to decompose it naturally (Budianto 2008). One of the ex-situ bioremediation management is by applying the technique of bio-slurry.

Bio-slurry use bioreactor such as container or reactors that be used for treatment of liquid or slurry. The slurry bioreactor is not only used to degrade liquid phase forms, but also solid phase wastes such as soil. Advantages of the bioremediation process by using slurry bioreactors are to accelerate mass transfer process between solid and liquid phases; to control parameters of environment, such as: soil nutrients, $\mathrm{pH}$, and temperature to be going well; to maintain level of acceptance of electrons in the reactor easily; and to prevent contamination of intruder microbes.

Oil Spill Dispersant (OSD) is a product that can break down waste oil into small parts so that it can be dispersed naturally (Elvina et al. 2016). This product consists of surfactants and several chemicals that were specially formulated to enhance the bioremediation process. Surfactant is an active component that decreases surface tension in the area between oil and water so that it can accelerate oil dispersion (Lidgren et al. 2001).

Surfactant and Bioenergy Research Center of Bogor Agricultural University (SBRC-IPB) has successfully developed OSD products derived from palm oil. Oil spill dispersant (OSD) is a combination of anionic surfactant/methyl ester sulfone (MES) and nonionic surfactant/dietanolamide (DEA). The results of previous studies indicated that nonionic surfactants and Linear Alkilbenzena Sulphonate (LAS) reduced oil content in solid phase waste (Charlena 2010) and liquid phase (Charlena et al. 2009). Adlina (2016) also stated that OSD derived from palm oil reduced total petroleum hydrocarbon 
(TPH) by $91.1 \%$ for 6 weeks of the bioremediation process.

Based on above mention, this study aimed to find out optimize and performance test of OSD in the process of bioremediation with using bio-slurry technique on contaminated soil with heavy oil.

\section{MATERIALS AND METHODS}

\section{Preparation of Contaminated Soil with Heavy Oil}

Petroleum contaminated soil samples were taken from petroleum companies in Sumatra. Soil sampling used randomized sampling method. Initial analysis of petroleum contaminated soils included: soil $\mathrm{pH}$, organic matter (C and $\mathrm{N}), \mathrm{P}$ and $\mathrm{K}$, exchangeable cation $(\mathrm{Ca}, \mathrm{Mg}, \mathrm{K}, \mathrm{Na}$, cation exchange capacity, and basis saturation), interchangeable $\mathrm{Al}$ and $\mathrm{H}$, interchangeable heavy metals $(\mathrm{Pb}, \mathrm{As}, \mathrm{Co}, \mathrm{Cd}, \mathrm{Cr}$, $\mathrm{Ag}$, and $\mathrm{Sn}$ ), oxalate $\mathrm{Fe}, \mathrm{Al}$, and $\mathrm{Si}$, and $\mathrm{TPH}$ levels. The initial analysis of contaminated soil samples are presented at Table 1.

\section{Preparation of Oil Spill Dispersant}

The experiment used OSD produced by SBRCIPB with materials from anionic and nonionic surfactants derived from palm oil. The anionic surfactant used was $1.5 \%$ DEA and non-ionic surfactant was $0.9 \%$ MES with a ratio of $7: 3$ formulation (Adlina et al. 2017).

\section{Preparation of Bacterial Inoculum}

The experiment used bacteria of Bacillus megaterium BM-PFFP (Syakti et al. 2013).

Table 1. Initial analysis of soil contaminated with heavy oil samples used in this study.

\begin{tabular}{|c|c|c|}
\hline Parameter & Method/ extraction & Average of contaminated soil \\
\hline $\mathrm{pH}\left(\mathrm{H}_{2} \mathrm{O}\right)$ & $\mathrm{pH}$ meter & 5.23 \\
\hline $\mathrm{pH}(\mathrm{KCl})$ & $\mathrm{pH}$ meter & 4.02 \\
\hline \multicolumn{3}{|l|}{ Organic matters } \\
\hline Org-C (\%) & $\begin{array}{l}\text { Walkley and } \\
\text { Black }\end{array}$ & 33.33 \\
\hline Tot-N (\%) & Kjehldahl & 0.42 \\
\hline $\mathrm{C} / \mathrm{N}$ & & 83 \\
\hline $\mathrm{P}_{2} \mathrm{O}_{5}\left(\mathrm{mg} \mathrm{Kg}^{-1}\right)$ & Bray 1 & 1.93 \\
\hline $\mathrm{P}_{2} \mathrm{O}_{5}\left(\mathrm{mg} \mathrm{Kg}^{-1}\right)$ & $\mathrm{HCl} 25 \%$ & 50 \\
\hline $\mathrm{K}_{2} \mathrm{O}\left(\mathrm{mg} \mathrm{Kg}^{-1}\right)$ & HCL $25 \%$ & 23.3 \\
\hline $\mathrm{K}_{2} \mathrm{O}\left(\mathrm{mg} \mathrm{Kg}^{-1}\right)$ & Morgan & 16.3 \\
\hline Exchangeable cation & $\mathrm{NH}_{4}-\mathrm{OAc} \mathrm{pH} 7$ & \\
\hline $\mathrm{Ca}\left(\mathrm{cmol} \mathrm{Kg}{ }^{-1}\right)$ & & 0.21 \\
\hline $\mathrm{Mg}\left(\mathrm{cmol} \mathrm{Kg}^{-1}\right)$ & & 0.10 \\
\hline $\mathrm{K}\left(\mathrm{cmol} \mathrm{Kg}{ }^{-1}\right)$ & & 0.03 \\
\hline $\mathrm{Na}\left(\mathrm{cmol} \mathrm{Kg}^{-1}\right)$ & & 0.08 \\
\hline $\mathrm{CEC}\left(\mathrm{cmol} \mathrm{Kg}{ }^{-1}\right)$ & & 6.49 \\
\hline BS (\%) & & 10.67 \\
\hline Exc.-Al $\left(\mathrm{cmol} \mathrm{Kg}^{-1}\right)$ & $\mathrm{KCl} 1 \mathrm{~N}$ & 0.1 \\
\hline Exc.-H $\left(\mathrm{cmol} \mathrm{Kg}^{-1}\right)$ & $\mathrm{KCl} 1 \mathrm{~N}$ & 0.23 \\
\hline \multicolumn{3}{|l|}{ Heavy metals } \\
\hline $\mathrm{Pb}\left(\mathrm{mg} \mathrm{Kg}^{-1}\right)$ & $\mathrm{HNO}_{3}$ & 10.38 \\
\hline $\mathrm{Cd}\left(\mathrm{mg} \mathrm{Kg}^{-1}\right)$ & $\mathrm{HNO}_{3}$ & 0.33 \\
\hline $\mathrm{Co}\left(\mathrm{mg} \mathrm{Kg}^{-1}\right)$ & $\mathrm{HNO}_{3}$ & 6.82 \\
\hline $\mathrm{Cr}\left(\mathrm{mg} \mathrm{Kg}^{-1}\right)$ & $\mathrm{HNO}_{3}$ & 18.35 \\
\hline $\mathrm{Ag}\left(\mathrm{mg} \mathrm{Kg}^{-1}\right)$ & $\mathrm{HNO}_{3}$ & 0.48 \\
\hline $\operatorname{Sn}\left(\mathrm{mg} \mathrm{Kg}^{-1}\right)$ & $\mathrm{HNO}_{3}$ & 0.66 \\
\hline As $\left(\mathrm{mg} \mathrm{Kg}^{-1}\right)$ & $\mathrm{HNO}_{3}$ & 18.35 \\
\hline $\mathrm{Fe}(\%)$ & Oxalate & 0.11 \\
\hline $\mathrm{Al}(\%)$ & Oxalate & 0.04 \\
\hline $\mathrm{Si}(\%)$ & Oxalate & 0.01 \\
\hline TPH $\left(\mathrm{mg} \mathrm{Kg}^{-1}\right)$ & Gravimetry & 105000 \\
\hline
\end{tabular}


Table 2. Range and extent of variable test of optimization.

\begin{tabular}{cccc}
\hline Treatment & Low level (-1) & Center level (0) & High level (+1) \\
\hline $\begin{array}{c}\text { Incubation time (day) } \\
(\mathrm{X} 1)\end{array}$ & 3 & 5 & 7 \\
$\begin{array}{l}\text { Dispersant to Oil } \\
\text { Ratio (DOR) (X2) }\end{array}$ & $0.5: 1$ & $1: 1$ & $1.5: 1$ \\
\hline
\end{tabular}

Bacteria were multiplied firstly in marine broth liquid media and then adapted to mineral media (Zhang et al. 2005). The one week grown inoculum was inoculated in soil contaminated with oil samples at a dose of $10 \% \mathrm{v} / \mathrm{w}$.

\section{Experimental Design}

\section{OSD Optimization}

Optimization on variable of TPH degradation, $\mathrm{pH}$, and total microbial used response surface method (RSM). Data processing used Design Expert of 10.01 with individual variables test which consisted of 3 levels. The details of it are presented at Table 2.

This experiment used an incomplete factorial design with 3 replications so that it met the quadratic model (Montgomerry 1997). The first factor was incubation time, namely: 3,5 , and 7 days; while the second factor was DOR, namely: 0.5:1, 1:1, and $1.5: 1$. With this procedure, there were 11 experimental units in this experiment. The center value of treatment was the incubation time of 5 day and DOR 1:1. Matrix of unit of experiments on bioremediation optimization of fractional composite designs are presented at Table 3.

Based on both variables test, the quadratic model followed this equation:

$$
\mathrm{Y}=\mathrm{b}_{0}+\mathrm{b}_{1} \mathrm{x}_{1 \mathrm{i}}+\mathrm{b}_{2} \mathrm{x}_{2 \mathrm{i}}+\mathrm{b}_{11} \mathrm{x}_{1 \mathrm{i}}{ }^{2}+\mathrm{b}_{22} \mathrm{x}_{1 \mathrm{i}}+\mathrm{ri}
$$

Note:

$\mathrm{Y} \quad$ : response of each treatment

$\mathrm{X}:(\mathrm{X} 1$ : Incubation time; X2: DOR)

$\mathrm{r}:$ : error

b : coefficient

\section{Test of OSD Performance with COD in Soil Solution}

Test of OSD performance was carried out using uncontaminated soil without OSD (blank-); uncontaminated soil with OSD (blank+); contaminated soil without OSD (TTM-); and contaminated soil with OSD (TTM + ). Furthermore, the measurement of COD was carried out on dissolved oil in soil solution (Clesceri et al. 2005).

\section{Bioremediation Application}

This experiment used reactor of $500 \mathrm{ml}$ (flask of $500 \mathrm{ml}$ with a working volume of $200 \mathrm{ml}$ ) and response surface method (RSM). Contaminated soil samples of $40 \%(\mathrm{w} / \mathrm{v})$ were treated with OSD, microbial consortium, and a combination of OSD and microbial consortium as shown at Table 3. Cultivation was carried out on a shaker at a speed of $180 \mathrm{rpm}$, at room temperature, for 7 days.

Table 3. Matrix of unit of experiments on bioremediation optimization of fractional composite designs.

\begin{tabular}{crrcc}
\hline No & Code factor I & Code factor II & $\begin{array}{c}\text { Factor I } \\
\text { Incubation time (day) }\end{array}$ & $\begin{array}{c}\text { Factor II } \\
\text { DOR }\end{array}$ \\
\hline 1 & -1 & -1 & 3 & $0.5: 1$ \\
2 & -1 & +1 & 3 & $1.5: 1$ \\
3 & +1 & -1 & 7 & $0.5: 1$ \\
4 & +1 & +1 & 7 & $1.5: 1$ \\
5 & 0 & 0 & 5 & $1: 1$ \\
6 & 0 & 0 & 5 & $1: 1$ \\
7 & 0 & 0 & 5 & $1: 1$ \\
8 & 1.414 & 0 & 7.8 & $1: 1$ \\
9 & -1.414 & 0 & 2.2 & $1: 1$ \\
10 & 0 & 1.414 & 5 & $1.7: 1$ \\
11 & 0 & -1.414 & 5 & $0.3: 1$ \\
\hline
\end{tabular}


Table 4. Analysis of variant of TPH biodegradation results.

\begin{tabular}{lccrrc}
\hline \multicolumn{1}{c}{ Source } & $\begin{array}{c}\text { Sum of } \\
\text { Squares }\end{array}$ & df & $\begin{array}{c}\text { Mean } \\
\text { Square }\end{array}$ & $\begin{array}{c}\text { F } \\
\text { Value }\end{array}$ & $\begin{array}{c}\text { p-value } \\
\text { Prob }>\text { F }\end{array}$ \\
\hline Model & 330.56 & 5 & 66.11 & 5.83 & 0.0194 \\
A-Time & 278.66 & 1 & 278.66 & 24.57 & 0.0016 \\
B-DOR & 12.44 & 1 & 12.44 & 1.10 & 0.3298 \\
\hline
\end{tabular}

\section{RESULTS AND DISCUSSION}

Based on a soil map of $1: 250,000$ scale, the soil at the experiment site included Podzolic (ICARRD 2014) or equivalent to Ultisol (Soil Survey Staff 2014). Levels of oil in the soil ranged between $102,000-107,000 \mathrm{mg} \mathrm{kg}^{-1}$ with an average of 105,000 $\mathrm{mg} \mathrm{kg}^{-1}$. This value showed that the soil had contaminated with heavy oil. Soil org-C ranged from 23.7 to $40.22 \%$ with an average of $33.33 \%$. This soil was not peat soil, but mineral soil (Podzolic) which was contaminated by heavy oil. Thus, very high levels of soil org-C were derived from oil contaminant, not from peat material.

To remediate the contaminated soil with heavy oil above may use ex-situ bioremediation such as slurry bioreactor technique. Slurry bioreactor was not only used to degrade waste in the form of liquid phase, but also in the form of solid phase (contaminated soil). According to Banerji (1997) the slurry phase could be obtained from solid waste/soil mixed with water so that the slurry had a density level of $10-40 \%$. The slurry was then stored in a bioreactor. Such an approach used nutrition and controlled environmental conditions so that microorganisms could carry out the degradation process very well (Kalbelitz et al. 2009; Militon et al. 2010; Simarro et al. 2013; Ros et al. 2014). Besides the addition of nutrients, gases or oxygen were given also to maintain aerobic conditions remain awake. Advantages of bioremediation process using slurry bioreactor were to speed up process of mass transfer between solid and liquid phases; to control environment, such as: nutrition, $\mathrm{pH}$, and temperature could run well; to maintain level of electron acceptance in the reactor easily; and to inhibit contamination of other microbes (Banerji 1997); Euan et al. 2015).

\section{Decrease of TPH}

Analysis of RSM on response of TPH biodegradation with incubation time and DOR factors followed this equation:
Note:

$\mathrm{Y}:$ : TPH degradation response

$\mathrm{X}_{1} \quad$ : Incubation time (days)

$\mathrm{X}_{2} \quad$ : DOR

Model analysis result showed that determinant coefficient value of $\mathrm{R}^{2}$ was 0.8063 . This indicated that $80.63 \%$ of TPH variance results were due to treatment variables. F-value of the model from analysis of variance showed significant results at probability of 0.0194. Likewise, F-value of incubation time showed a significant result at probability of 0.0016 (Table 4.). This indicated that incubation time treatment and its combination with DOR (model) significantly affected on level of soil biodegradation of hydrocarbons.

The experiment results showed that the optimum conditions of bioremediation were achieved at decrease of TPH at certain both incubation time and DOR. Response of surface of TPH decomposition of incubation time and DOR optimization results were presented at Figure 1. It showed that the optimum conditions were reached at DOR 1.16:1 and incubation time of 7 days which were able to decompose TPH of $54.30 \%$. The experiment results indicated that the addition of OSD

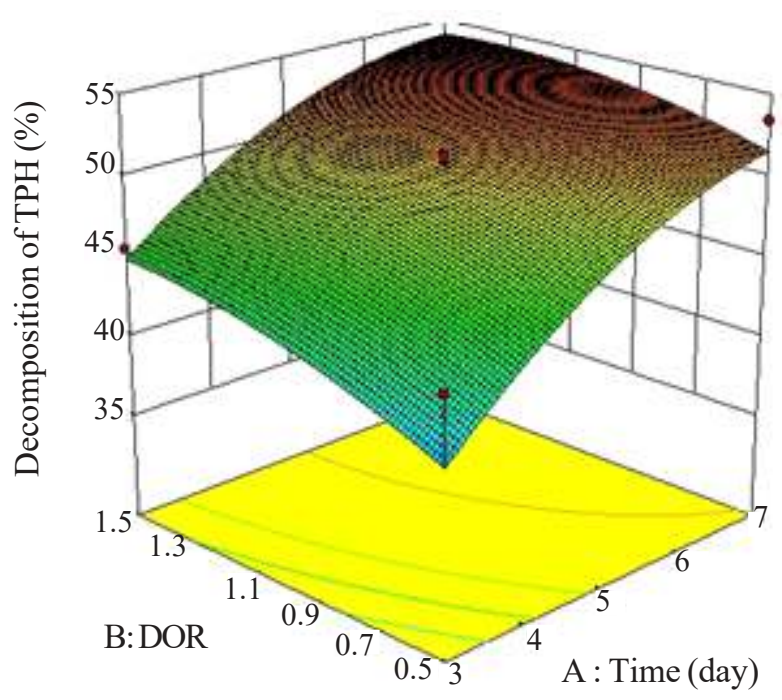

Figure 1. TPH decomposition response surface. 
Table 5. Analysis of variance of soil $\mathrm{pH}$.

\begin{tabular}{llllll}
\hline \multicolumn{1}{c}{ Source } & \multicolumn{1}{c}{$\begin{array}{c}\text { Sum of } \\
\text { Squares }\end{array}$} & df & \multicolumn{1}{c}{$\begin{array}{c}\text { Mean } \\
\text { Square }\end{array}$} & $\begin{array}{c}\text { F } \\
\text { Value }\end{array}$ & $\begin{array}{c}\text { p-value } \\
\text { Prob }>\text { F }\end{array}$ \\
\hline Model & 0.16 & 5 & 0.032 & 4.27 & 0.0423 \\
A-Time (day) & 0.028 & 1 & 0.028 & 3.79 & 0.0926 \\
B-DOR & 0.021 & 1 & 0.021 & 2.81 & 0.1373 \\
\hline
\end{tabular}

was able to accelerate hydrocarbon decomposition processes. Same results were reported by Charlena (2010) and Chanif (2017) which stated that addition of surfactant from palm oil accelerated the process of light oil hydrocarbon decomposition. Surfactant had characteristics of lowering surface tension between hydrocarbons with soil, so that hydrocarbons might disperse to natural solution of water (slurry) and easier to decompose.

Amount of hydrocarbons present in solids of the slurry could be seen from the TPH value at a certain period of incubation time at bio-slurry technique. At optimum conditions (DOR 1.16:1 and 7 days observation time), TPH decreased by $54.30 \%$, or there was decline from 105,000 to 47,985 $\mathrm{mg} \mathrm{kg}$. These were consistent with results of experiment conducted by Euan et al. (2015) which reported that TPH values in solids might indicate the rate of decomposition of hydrocarbons in heavy oils.

\section{Environmental Acidity Conditions (Soil pH)}

Analysis of RSM on response of acidity condition (soil $\mathrm{pH}$ ) with incubation time and DOR factors followed this equation:

\section{$Y=8.83-0.06 \mathrm{X} 1+0.051 \mathrm{X} 2+0.032 \mathrm{X} 1 \mathrm{X} 2-0.12 \mathrm{X}^{2}-0.054 \mathrm{X} 2^{2}$}

Note:

$\mathrm{Y}:$ Soil $\mathrm{pH}$

$\mathrm{X}_{1}$ : Incubation time (days)

$\mathrm{X}_{2}$ : DOR

Model analysis result showed that determinant coefficient value of $\mathrm{R}^{2}$ was 0.7529 . This indicated that $75.29 \%$ of acidity condition variance results were due to treatment variables. F-value of model from analysis of variance showed significant results at probability of 0.0423 . Likewise, F-value of incubation time showed a significant result at probability of 0.0925 (Table 5). This indicated that incubation time treatment and its combination with DOR (model) significantly affected on level of soil $\mathrm{pH}$.
Soil acidity response surface of optimization results both DOR and incubation time are presented in Figure 2. It showed that optimum conditions were reached at 1:1 DOR and 5 day incubation time with a pH value of 8.825. Generally, Bacillus megaterium may grow and develop on environmental conditions of soil $\mathrm{pH}$ around 7-9. Good environmental conditions could increase activity of microbe metabolism in decomposing oil. This condition could stimulate the Bacillus megaterium to produce biosurfactants. Experiment result reported by Nuning (2009) that B. megaterium could produce biosurfactant of $2.634 \mathrm{~g} \mathrm{~L}^{-1}$ at favorable environment conditions.

In addition, Yaohui and Mang (2010) explained that favorable environmental conditions $(\mathrm{pH}$, temperature, and humidity) could improve biodecomposition of hydrocarbons by microbes. The level of soil acidity $(\mathrm{pH})$ affected the growth and the activity of microbes in decomposing hydrocarbons. García Frutos et al. (2012) explained also that soil acidity was one of the favorable factors that influenced rate of bacterial growth, ability of bacteria to build cells, and balance of catalyst reactions.

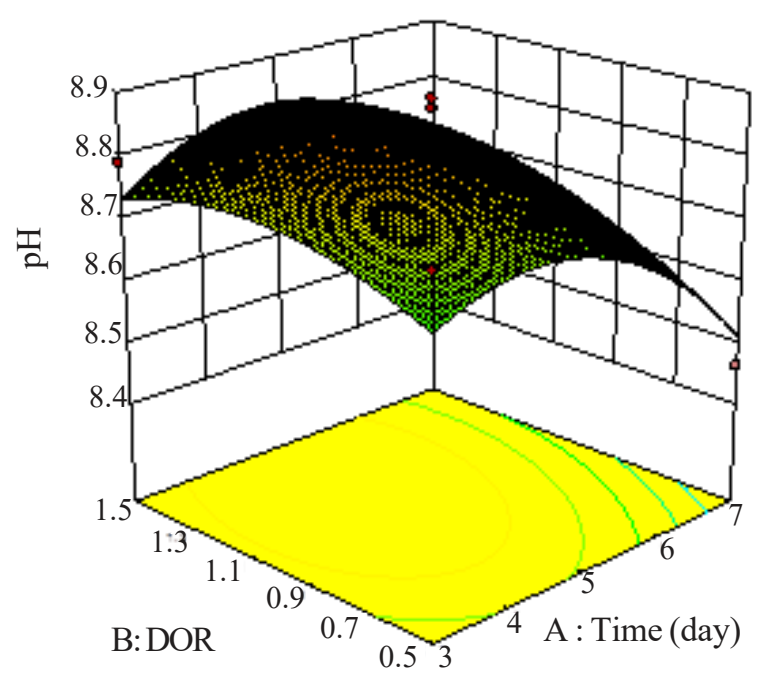

Figure 2. Surface response levels of soil $\mathrm{pH}$. 
Table 6. Analysis of variance of total population B. megaterium.

\begin{tabular}{llllll}
\hline \multicolumn{1}{c}{ Source } & \multicolumn{1}{c}{$\begin{array}{c}\text { Sum of } \\
\text { Squares }\end{array}$} & df & \multicolumn{1}{c}{$\begin{array}{c}\text { Mean } \\
\text { Square }\end{array}$} & $\begin{array}{c}\text { F } \\
\text { Value }\end{array}$ & \multicolumn{1}{c}{$\begin{array}{c}\text { p-value } \\
\text { Prob }>\text { F }\end{array}$} \\
\hline Model & 3.25 & 5 & 0.65 & 28.29 & 0.0002 \\
A-Time (day) & 3.10 & 1 & 3.10 & 135.18 & $<0.0001$ \\
B-DOR & $2.481 \mathrm{E}-003$ & 1 & $2.481 \mathrm{E}-003$ & 0.11 & 0.7519 \\
\hline
\end{tabular}

\section{Bacterial Population Growth}

Analysis of RSM on response of total microbes with incubation time and DOR factors followed this equation:

\section{$Y=786+0.62 X 1+0.018 X 2-0.054 X 1 X 2-0.13 \times 1^{2}-0.036 \times 2^{2}$}

Note :

Y : Total microbes

$\mathrm{X} 1 \quad$ : Incubation time (days)

$\mathrm{X} 2$ : DOR

Model analysis result showed that determinant coefficient value of $\mathrm{R}^{2}$ was 0.9528 . This indicated that $95.28 \%$ of total microbe variance results were due to treatment variables. F-value of the model from analysis of variance showed significant results at probability of 0.0002 . Likewise, F-value of incubation time showed a significant result at probability of $<0.0001$ (Table 6 ). This indicated that incubation time treatment and its combination with DOR (model) significantly affected the level of total population of $B$. megaterium.

Total microbe of $B$. megaterium response surface of optimization results both DOR and incubation time are presented in Figure 3. It showed that optimum conditions were reached at $0.86: 1$ DOR and 7 day of incubation time with a total microbe of $B$. megaterium value of $8.35 \mathrm{log} \mathrm{CFU}$ $\mathrm{g}^{-1}$. This indicated that there was an increase in the population of $B$. megaterium bacteria due to incubation time and its combination with DOR. The increase in the number of bacteria was an indication that the bacteria grow well by consuming hydrocarbons as a carbon source for the purposes of their growth and development. This was explained by Liado et al. (2012) and Benedek et al. (2013) which stated that hydrocarbon decomposition bacteria utilize the contaminant of petroleum as their carbon source.

In addition, experiment results of Eun-Hee et al. (2011) also showed that the Bacillus megaterium could grow well up to $50 \%(\mathrm{v} / \mathrm{v})$ of oil sludge concentration. Both indigenous and exogenous bacteria were important factors in the process of oil bio-decomposition (Aler et al. 2014). All showed that B. megaterium was a great potential to decompose petroleum contaminants.

\section{Chemical Oxygen Demand (COD) in Soil Solution}

F-value models of analysis of variance showed that the results were not significant (data not shown). Nevertheless, value of COD in soil solution of contaminated soil with OSD treatment was 2,732 $\mathrm{mg} \mathrm{L}^{-1}$, higher 3.8 fold compared with contaminated soil without OSD treatment $\left(720 \mathrm{mg} \mathrm{L}^{-1}\right)$ even 6.36 fold as much compared to the uncontaminated soil with OSD (430 $\mathrm{mg} \mathrm{L}^{-1}$ ) (Figure 4). This showed that addition of OSD could dissolve oil into the soil solution. Dissolved oil in soil solution could increase soil COD value. It means that there was an increase level of hydrocarbons in soil solution, so amount of oxygen needed to oxidize hydrocarbons to $\mathrm{CO}_{2}$ and $\mathrm{H}_{2} \mathrm{O}$ increased. Chemical oxygen demand was amount of oxygen required to oxidize organic materials chemically (APHA 1992). The high content of COD indicated the high number of organic matters in a solution.

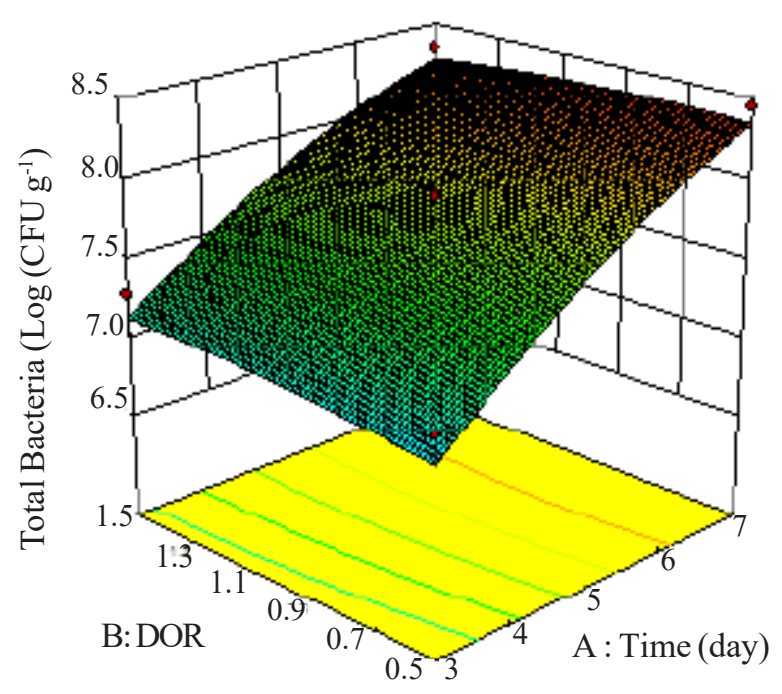

Figure 3. Total microbe response surface. 


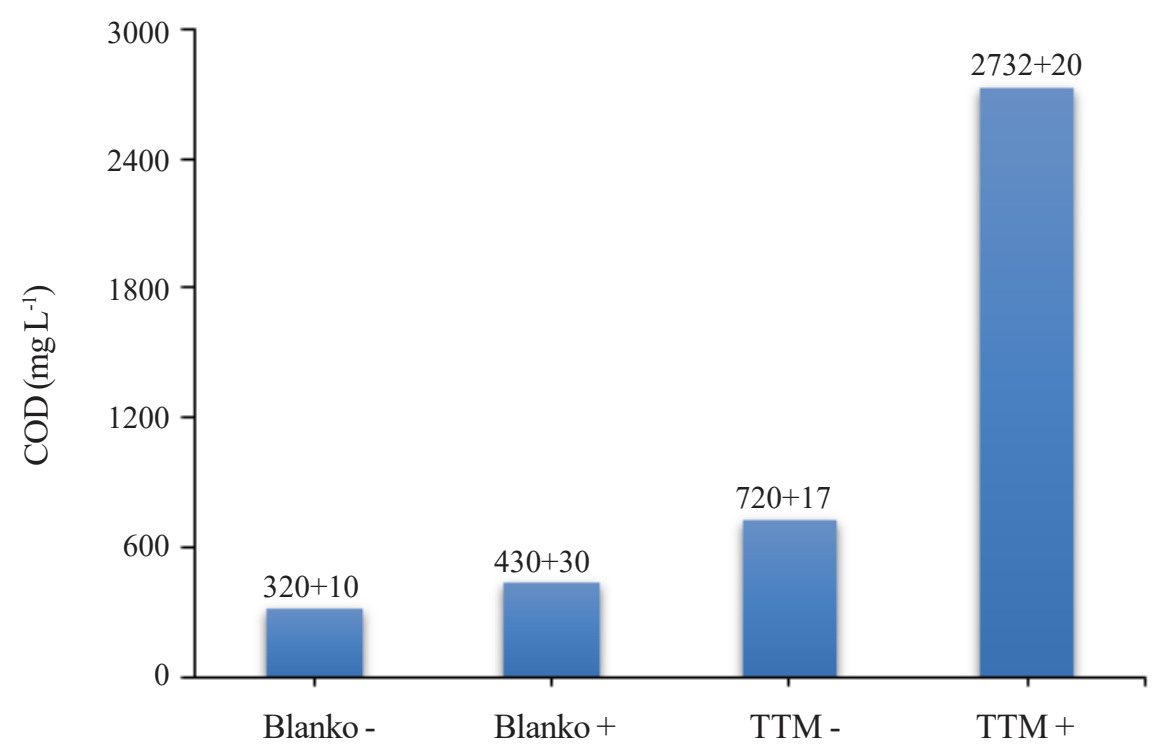

Figure 4. Chemical oxygen demand (COD) in solution of contaminated soil treated with OSD. * Blank- : Uncontaminated soil without OSD; Blank+: Uncontaminated soil with OSD; TTM-: Contaminated soil without OSD; TTM+: Contaminated soil with OSD.

Charlena et al. (2009) believed that solubility of oil in water increased COD value of petroleum waste. Suardana et al. (2002) also reported that waste of petroleum treated with surfactant improved solubility of oil in water due to dispersion of oil into smaller particle. The oil from pores of contaminated soil could be released and moved into soil solution so that oil content in the soil solution increased and soil COD value also increased.

In addition, application of OSD into the soil also increased soil COD value (Figure 4). The COD value of uncontaminated soils without OSD (320 $\mathrm{mg} \mathrm{L}^{-1}$ ) was much lower than those of uncontaminated soils with OSD $\left(430 \mathrm{mg} \mathrm{L}^{-1}\right)$. The application of OSD increased soil COD because OSD SBRC-IPB itself was an organic compound derived from palm oil, so that number of organic compounds to be oxidized (COD) increased. Elvina et al. (2016) stated that application of OSD increased value of COD in solution due to their dispersion of OSD in seawater.

\section{CONCLUSIONS}

The treatment of incubation time and its combination with DOR significantly reduced soil TPH, increased soil acidity, and increased soil total B. megaterium, but did not significantly affect on COD in soil solutions. Optimization of OSD with RSM showed that the higher DOR of OSD and the longer of incubation time, the higher also the rate of biodegradation of TPH. The optimum conditions were reached at DOR of 1.16:1 and incubation time of 7 days that were able to degrade soil TPH of $54.30 \%$. The optimum conditions of soil $\mathrm{pH}(8.825)$ was reached at DOR of 1:1 and incubation time of 5 days, as well as the optimum conditions of $B$. megaterium (8.35 $\log \mathrm{CFU} / \mathrm{g}$ ) was reached at DOR of $0.86: 1$ and incubation time of 7 days. Oil spill dispersant (OSD) increased COD in soil solution in both uncontaminated and contaminated soils with heavy oil.

\section{ACKNOWLEDGEMENTS}

The authors would like to thank The Surfactant and Bioenergy Research Center (SBRC) Laboratory - Bogor Agricultural University for financial support and excellent technical assistance.

\section{REFERENCES}

Adlina S. 2016. Kinerja OSD (Oil Spill Dispersant) dari Surfakktan Minyak Sawit dengan Penambahan Pseudomonas aeruginosa IPBCC.b11662 Untuk Bioremediasi Tanah Tercemar Hidrokarbon Minyak Bumi [Tesis]. Institut Pertanian Bogor. Bogor (ID). (in Indonesian).

Adlina S, M Yani and E Hambali. 2017. Oil spill dispersant (OSD) formulation of palm oil base surfactant for bioremediation of soil contaminated hydrocarbons. Chem Process Eng Res 53: 1-12. 
APHA [American Public Health Association]. 1992. Standard Methods for the Examination of Water and $18^{\text {th }}$ Wastewater. edition. Washington DC: APHA, AWWA\& WEF.

Banerji SK. 1997. Bioreactor for Soil and Sediment Remediation. In: RK Bajpai and ME Zappi (eds). Bioremediation of Surface and Subsurface Contamination. New York. The New York Academy of Sciences.

Benedek T, B Vajna, A Tancsics, K Marialigeti, S Lanyi and I Mathe. 2013. Remarkable impact of PAHs and TPHs on the richness and diversity of bacterial species in surface soils exposed to long-term hydrocarbon pollution. J. Microbiol Biotechnol 29:1989-2002.

Budianto H. 2008. Perbaikan Lahan Terkontaminasi Minyak Bumi Secara Bioremediasi. Jakarta: Indonesia Environment Consultant. (in Indonesian).

Center Bureau of Statistics. 2016. BP Statistical Review of World Energy. London (GB): BP statistical

Chanif I, H Erliza and M Yani. 2017. Kinerja oil spill dispersant dalam proses bioremediasi tanah tercemar minyak bumi (studi kasus tanah tercemar minyak bumi lapangan XYZ). J Tek Industri Pertanian 27: 336-344. (in Indonesian).

Charlena, ZAlim Mas'ud, A Syahreza and AS Purwadayu. 2009. Profil kelarutan limbah minyak bumi dalam air akibat pengaruh surfaktan nonionik dan laju pengadukan. Chem Prog 2: 69-78. (in Indonesian).

Charlena. 2010. Bioremediasi Tanah Tercemar Limbah Minyak Berat Menggunakan Konsorsium Bakteri [Disertasi]. Insitut Pertanian Bogor. Bogor (ID). (in Indonesian).

Chithra S and SN Hema. 2014. Isolation and identification of oil degrading bacteria from oil contaminated soil and comparison of their bioremediation potential. GJRA 3: 181-184.

Clesceri RW, Greenberg AE, dan Eaton AD. 2005. Standard Methods for The Examination of Water and Wastewater, edition 20 $0^{\text {th }}$. Washington (US): American Public Health Association Pr.

Dindar E, Paðban FOT, Ba ${ }^{\circ}$ kaya HS. 2013. Bioremediation of petroleum-contaminated soil. J Biol Environ Sci 7:39-47.

Elvina W, H Erliza and M yani. 2016. Formulasi dispersan minyak bumi dari surfaktan dietanolamida (DEA) dan metil ester sulfonat (MES). J Teknologi Industri Pertanian 26: 104-110. (in Indonesian).

Euan S, S Prashant, P Thavamani, K Ramadass, N Ravi and M Mallavarapu. 2015. Remediation trials for hydrocarbon-contaminated soils in arid environments: evaluation of bioslurry and biopiling techniques. Int Dech Monog 101: 56-65.

Eun-Hee L, YS Kang and KS Cho. 2011. Bioremediation of diesel-contaminated soils by natural attenuation, biostimulation and bioaugmentation employing Rhodococcus sp. EH831. Korean J Microbiol Biotechnol 39: 86-92.
Frutos FJG, RPO Escolano, A Rubio, A Gimeno, MD Fernandez, G Carbonell, C Perucha and J Laguna. 2012. Remediation trials for hydrocarboncontaminated process: sludge from a soil washing Evaluation of bioremediation technologies. $J$ Hazard Mat 200: 262-271.

ICARRD [Indonesian Center for Agricultural Resources Research and Development]. 2014. Soil National Taxonomy. Agricultural Research and Development Agency, Indonesian Ministry of Agriculture.

Kalbelitz N, J Machackova, G Imfeld, M Brennerova, DH Pieper, HJ Heipieper and H Junca. 2009. Enhancement of the Microbial Community Biomass and Diversity During Air Sparging Bioremediation of a Soil Highly Contaminated with Kerosene and BTEX. Appl Microb Biotechnol 82: 565-577.

Liado S, AM Solanas, J de Lapuente, M Borras and M Vinas. 2012. A diversiûed approach to evaluate biostimulation and bioaugmentation strategies for heavily-oil-contaminated soil. Sci Total Environ 435: 262-269.

Lidgren C, L Helene and F Jonas. 2001. Oil Spill Dispersant Risk Assessment for Swedish Waters. IVL Publication service. Stockholm

Liu PWG, TC Chang, LM Whang, CH Kao, PT Pan and SS Cheng. 2011. Bioremediation of petroleum hydrocarbon contaminated soil: Effects of strategies and microbial community shift. Dech Monog 65:1119-1127.

Margesin R and F Schinner. 2001. Bioremediation (natural attenuation and biostimulation) of diesel-oilcontaminated soil in an alpine glacier skiing area. Appl Env Microbiol 67: 3127-3133.

Militon C, D Boucher, C Bachelard, G Perchet, V Barra, J Troquet, E Peyretaillade and P Peyret. 2010. Bacterial community changes during bioremediation of aliphatic hydrocarbon-contaminated soil. FEMS Microbiol Ecol 74: 669-681.

Montgomery DC. 1997. Design and analysis of experiments, 4th edition. John Wiley \& Sons. New York.

Nugroho A. 2007. Biodegradasi 'sludge' minyak bumi dalam skala mikrokosmos. Makara Teknologi 10: 82-89.

Nuning Vita H. 2009. Produksi biosurfaktan oleh Bacillus megaterium dan pengaruhnya terhadap biodegradasi polyaromatic hydrocarbons (PAHs) [Tesis]. Institut Pertanian Bogor. Bogor (ID). (in Indonesian).

Ros M, I Rodríguez, C García and MT Hernandez. 2014. Bacterial community in semiarid hydrocarbon contaminated soils treated by aeration and organic amendments. Int Biodeterior Biodegrad 94: 200206.

Simarro R, LF Gonzaleza, N Bautistab and MC Molinaa. 2013. Assessment of the efûciency of in situ bioremediation techniques in a creosote polluted soil: change in bacterial community. J Hazard Mater 262: $158-167$. 
Soil Survey Staff. 2014. Kunci Taksonomi Tanah. Edisi Ketiga, 2015. Balai Besar Penelitian dan Sumberdaya Lahan Pertanian. Badan Penelitian dan Pengembangan Pertanian, Kementrian Pertanian. (in Indonesian).

Suardana P, M Mulyono, S Setyo, D Supardi and E Santoso. 2002. Pengaruh surfaktan alkilbenzena sulfonat linear dalam mempercepat bioremediasi limbah minyak bumi. Simposium Nasional-IATMI, Jakarta. (in Indonesian). Syakti AD, M Yani, NV Hidayati, AS Siregar, P Doumenq and IM Sudiana. 2013. The bioremediation potential of hydrocarbonoclastic bacteria isolated from a mangrove contaminated by petroleum hydrocarbons on cilacap coast, Indonesia. J Bioremed 17:11-20.
Yaohui Xu and Lu Mang. 2010. Bioremediation of crude oil-contaminated soil: comparison of different biostimulation and bioaugmentation treatments. J Hazardous Materials 183: 395-401.

Zhang G, W Yue-ting, Q Xin-ping and M Qin. 2005. Biodegradation of crude oil by Pseudomonas aeruginosa in the presence of rhamnolipids. $J$ Zhejiang University Science. 6B: 725-73. 